〔日農医誌 61 巻 6 号 830 834頁 2013. 3 3

\title{
公開講座 I：
}

\section{食と健康}

\section{——その最先端科学の歩みをたどり，食育への応用の途をさぐる—}

\section{阿 部 啓子*}

日本には古くから「医（薬）食同源」の考え 方が中国から伝えられていて，実践もされてい たようだ。一方，古代ギリシャの医師ヒポクラ テスは「食を汝の薬とせん，薬を汝の食とせ ん」という言葉を遺している。私たちの先人 は，洋の東西を問わず大昔から，食物を薬のよ うに，薬を食物のように把え，病気を防き健康 を保つことに大きな関心を抱いていたことがわ かる。しかし，この関心は必ずしも科学に裏づ けられたものではなかった。

科学としての食の研究は 20 世紀に入ってから 本格的に始まった。しかもその狙いは栄養素の 解明だった。日本に偉大な栄養学者が現れた。 農芸化学者・鈴木梅太郎先生がその人である。 米糠からビタミン $\mathrm{B}_{1}$ (というよりも現在知ら れている13種類のビタミンの第 1 号) を発 見，1914年にはノーベル医学生理学賞候補にド イッ学派から推挙された。

一方, 化学者・池田菊苗先生はほぼ同じ頃, 昆布から旨味成分グルタミン酸ナトリウム

（MSG）を分離した。これは味覚科学という 新しい研究分野を拓き, そして近代食品・発酵 産業の発祥に大きく貢献した。

こうして, 第二次大戦前から戦後にかけて, 栄養と味覚（さらには“おいしさ”）の研究は 日本の食品科学のみならず世界のそれの二大潮 流となった。産業的には，とりわけ1960年頃に 始まった高度経済成長の時期に, 栄養豊富で風 味絶佳の食品の開発・製造が盛んになり，私た ちの食生活を潤したのである。

₹113-8654 東京都文京区本郷7-3-1

* 東京大学名誉教授 - 大学院農学生命科学研究科特任教授
ところが世紀末になって, 人々の間に過食や 偏食といった食生活の乱れが目立つようになっ た。しかも，運動不足や喫煙過多といった生活 習慣上の問題がこれに加わり, 糖尿病・高血 圧・高脂血症・肥満症などの原因となるメ夕ボ リックシンドローム（代謝症候群）や，がん・ アレルギー・感染症などの原因となる免疫不全 が大きな社会問題として浮上してきた。高齢化 社会の到来がこれに拍車をかけた。

呼応して, この問題に対処する学術研究がス タートした。その代表例は文部省（現在の文部 科学省）の助成による「機能性食品研究班」

（代表者：荒井綜一ら）の活動で, ここで初め て，現代科学に裏づけられた「医食同源」とも いうべき「機能性食品」のアイテムが登場し た。1984年のことであった。

「研究班」は，からだに対する食品とその成 分の働き（機能）を, (1)健康の維持・増進に必 要な栄養素の機能 (一次機能), (2)食品のおい しさを生み出す嗜好成分たとえば味や香りの成 分の感性機能 (二次機能), (3)病気の一次予防 （病気にならないようにすること）の助けとな る非栄養性成分の生理学上の機能 (三次機能) に分類した。食品機能論の誕生である。

三次機能こそいま社会問題になっている生活 習慣病 (前述) の対策に不可欠な研究対象で, これを研究する新科学を食品機能学という。各 大学の栄養学科のカリキュラムも取り入れられ ている。「研究班」は三次機能が勃果的に現れ るように設計され製造された新食品を「機能性 食品」と命名した。その最初の例は, 普通米を 酵素処理して作製した低アレルゲン米だった。 行政も動いた。厚生省（現在の厚生労働省）は 
国の厳格な審査に合格した機能性食品を特定保 健用食品（トクホ）の名で認可する制度を1991 年に発足させた。

自然科学の最高峰の国際誌である「ネイ チャー」は1993年，わが国の学術，行政面での こうしたハイライトを「日本は食と医の境界に 踏み込む」という魅力的な見出しで大きく報道 した。現代科学と厚生行政を基盤とした「医食 同源」の登場といって過言ではない。

それが海外諸国，とくに欧米各国に与えるイ ンパクトはきわめて大きかった。日本発の科 学・行政が世界を動かした数少ない例の 1 つと 見てよいであろう。

機能性食品を特徵づける成分は，栄養素（夕 ンパク質，糖質，脂質，ミネラル，ビタミン） というよりも，いわゆる非栄養性物質（ポリ フェノール，カロテノイド，オリゴ糖，オリゴ ペプチドなど）である（図 1 )。これらは栄養 素や医薬品と明らかに区別される（図 2 )。こ うした特徵から，国が認可した機能性食品とい うべき特定保健用食品（略称卜クホ）の制度が 発足したわけである。現在（2012年12月）まで に1,000を超すトクホ商品が認可されている。 これが “食と健康” ブームの下支えとなってい ることも否めない。

ところで，食品にとってきわめて重要な条件
は何だろうか一それは“おいしさ”である。医 薬品と違って食品は, 毎日毎日, 多量に消費し 続けるのであるから，おいしくなければ続かな い。ここに，味覚の存在意義がクローズアップ されてくる。

一般に，感覚は動物が環境に適応しつつ生き ながらえる上での羅針盤みたいなものである。 味の感覚 (味覚) は, 動物が外界から自分に とって有益な物質を取り达み，有害な物質を取 り込まないようにするシグナルなのである。つ まり味覚は生きる上での指針であり, その研究 はすでに生命科学（ライフサイエンス）の主要 な一部とさえなっている。一方で，人間にとっ て重要な伝統的食文化の形成に，そして現代食 品産業・農水畜産業の構築の基盤となったのも “味”に他ならない。

食べ物の中にある物質が味を呈するのは，舌 上の味蕾でその物質が受け取られるからであ る。しかも, 甘味, 旨味, 苦味, 酸味, 塩味は それぞれ別々の味蕾細胞に受け取られる。つま り，5つの味の受容体はそれぞれ別々の細胞に 発現している。この中で, 甘味の感覚は人類に とって最もファミリアーなものであり，さまざ まな甘味物質が開発されているが，甘味受容体 はたった 1 種類なのである。研究では，ケース スタディーとして，甘味を与える物質（外来）

\begin{tabular}{|c|c|}
\hline 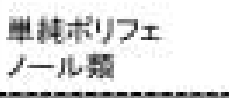 & $\begin{array}{l}\text { ほほ全ての } \\
\text { 植物性最品 }\end{array}$ \\
\hline フラボン粗 & 柑转数とハーフ \\
\hline フラポノール霜 & 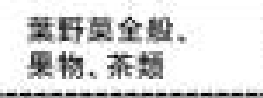 \\
\hline インフラボン断 & 大豆、需 \\
\hline フラパハン颗 & 拑的顛 \\
\hline カテキン制 & 萧粗、ב \\
\hline アントンアニン数 & 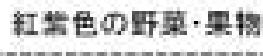 \\
\hline アントラキンン䕎 & 㴗方の莱草 \\
\hline
\end{tabular}

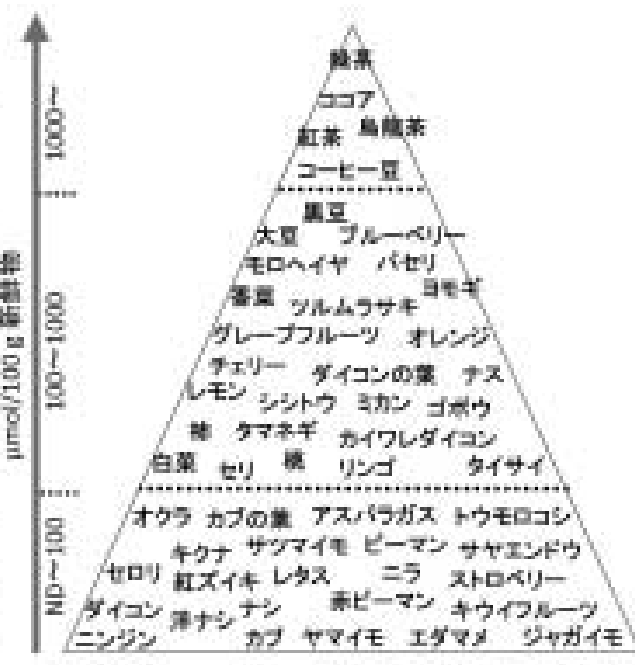

ポリフェノール合量ビラミッド

[荒井・阿部・金沢・吉川・渡邊共編「機能性食品の事典」朝倉書店（2007）］

図 1. 食品と抗酸化・抗老化成分ポリフェノール 


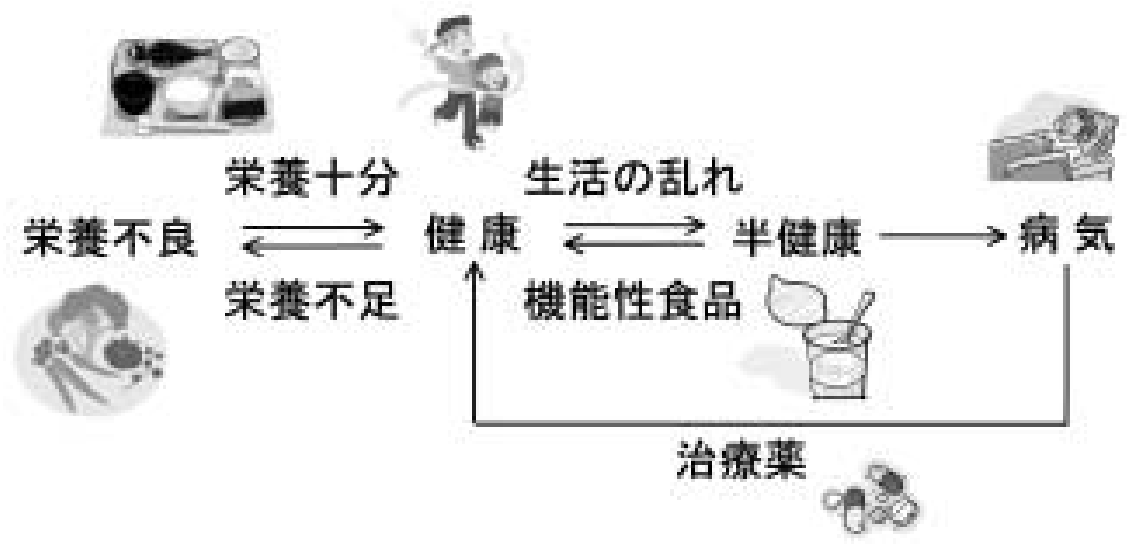

図 2. 栄養・治療薬と比較した機能性食品の位置づけ

と，その受容体（内生）が遭遇する事象の分子 レベルでの解明が必要だと思っている。

筆者らは，ユニークな甘味物質として，熱帯 植物果実に含まれている，酸味を甘味に変える タンパク質（ネオクリンと命名）を研究に用い てみた。まず，その構造をX 線解析した後, 甘味受容体とのドッキングモデルをシミュレー トし，どのように甘味受容体と結合して味のシ グナルを発信するかを明らかにした。最近，同 様のタンパク質であるミラクリンおよび人工甘 味料がヒト甘味受容体とどのようにドッキング するかのモデルを提示した。

味蕾でキャッチされた食品の味は，最終的に は脳で“どんな味”かが判断される。では，感 覚シグナルがどのように神経を伝わって脳に達 するのだろうか。しかも，重要なことは，それ ぞれの味がどのような道筋で脳に伝導されるか という点である。その伝導路についても，小麦 肧芽レクチンという神経間を動くトレーサーを 動物に適用して解明した。その結果, 甘味, 旨 味, 苦味, 酸味が, すべて別々の神経細胞に よって伝達されることを確認した。

食べ物に含まれる味のシグナルは味神経を伝 わって脳に達し，そこで味が認知されて初めて おいしい／まずい，好き／嫌い，食べる／食べ ないという私たちの摂食行動を生み出す。知り たいことは，この物質がどういう摂食行動を起 こさせるのか，体にとってどうなのかであり， その研究をも行なっている。興味深いのは，ヒ トのこうした味覚行動は生まれたばかりの赤
ちゃんにも見られるという点で (図 3 ), 私た ちがこの世に生を得た時から味覚は動き始めて いる。「三つ子のたましい百まで」といわれる 所以である（図 4 ）。

ごく最近, 筆者らのグループは, 乳児が乳汁 から離乳食へと切り替わることの意味の一端を 脳内での遺伝子発現変化から説明しようとする 研究を開始した。とくに hsp 群（ヒートショッ ク・タンパク質遺伝子群）が離乳食の摂取によ り，栄養面は乳汁と同等に精製してあるにもか かわらず，有意に上昇し始めた。脳の発育と関 係するのかもしれない。脳の発育は当然に味覚 の発達に寄与するであろう。それは，成人の， さらには老人の $\mathrm{QOL}$ の改善に結びつく。味覚 を基盤とした食育の意義の解明が待たれるのは 正にこの点にある。

食育の基本目標として

(1)自然環境と食料生産の関係・食材の由来を 理解する一食は自然の恵みと人々の営みの 所産……（自然環境と農業の価値）

(2)食事を作ることに共感をもち，自ら食事を 作る技能を身につける一調理とおいしさの 源を確かめ，作る愉しさを発見する…… (作る・人間らしい食の価值)

(3)味覚を啓発し，味の多様性を知り，食を表 現する力を養う一五感で体験し, 味を確か め，ともに食べる愉しさ……（味わう・人 間らしい食の価值)

(4)身体・健康・生命と食事・栄養の結びつき を理解する一生命・健康は食で維持される 


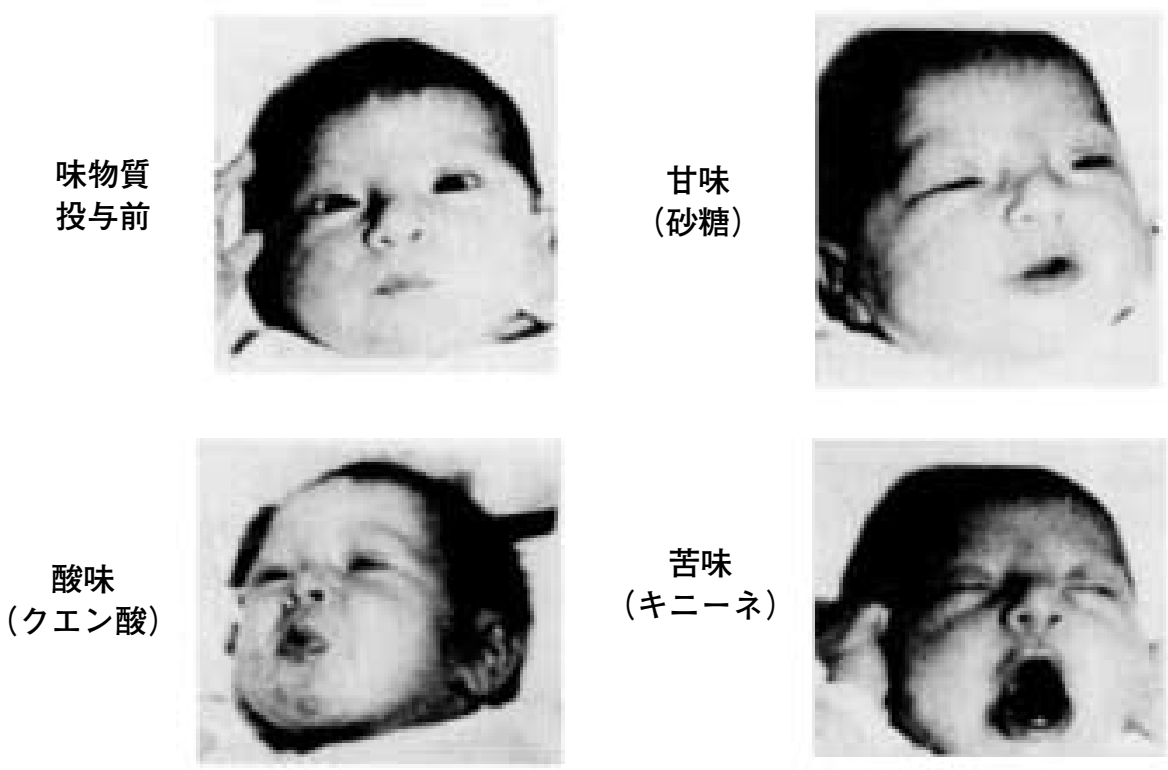

[阿部，山本ら共著「食と味覚」建帛社，p.75（2008）より改変]

図 3. 新生児が示す好き嫌いの表情

\section{食育の学術背景の一例}

\section{新しい“食と腦"領域研究一三つ子の魂 百まで}

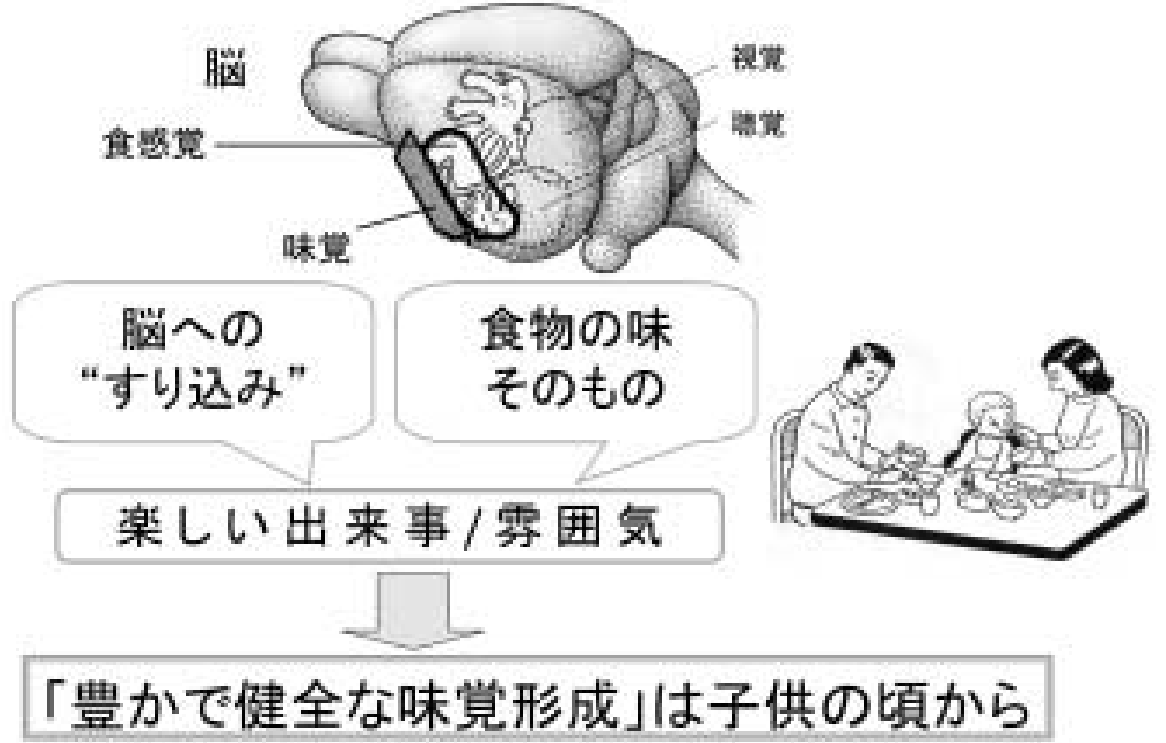

図 4.味覚の先端科学と食育

大切さ, 命の尊さ…… (生命・健康の価 值)

(5)食文化・食事作法を学び，味覚・食を受け 継ぎ，発展させる一人間と歴史・地理・食 事の広がり・ともに食べる幸せ……（食文 化の価値)

が提唱されている。この中で(3)が味覚に関係
する。味覚を主軸とする食育の意識は図 4 の ように説明できると筆者は考えている。

食品科学の研究は，鈴木梅太郎先生をルーツ とする栄養の研究と, 池田菊苗先生をルーツと する嗜好（おいしさ）の研究に，20世紀後半， 病気予防という生理機能面の研究が加わり，卜 
ライアングルとして発展を遂げてきた。ところ が，栄養，感性，生理調節はばらばらではな く，匂いがストレスを軽減するように，また味 が消化管で感知されるように，密接に連動して いるはずである。このことは，近未来の第 3 世 代の統合食品機能学とその産業の出現を示唆し ている。

鈴木梅太郎博士直伝の農学生命科学的 “食と 健康”の研究は, 物証を重視する現代栄養科学 の発展の基礎となった。そこから，栄養素とは 別の，病気の予防に寄与する “非栄養性機能成 分”というアンチテーゼが生まれ，機能性食品
の科学と, 関連産業の国際的展開が始まった。 機能性食品の研究に, ゲノミクス・エピジェネ ティクスという遺伝子科学が導入され，テー ラーメード食品（仕立てられた食品）が創られ る可能性も出てきた。その一方で，嗜好（おい しさ）を重視する日本の食品科学は, 味覚・嗅 覚の先端研究でも世界のトップに躍り出た。そ して近い将来, 上述したように, 栄養科学, 食 品機能学, 感性科学を統合させた第 3 世代の食 の生命科学が，各国に誕生すると期待されるの である。 